Policy Research Working Paper 6300

Saving and Growth in Sri Lanka

Constantino Hevia

Norman Loayza

The World Bank

Development Research Group

Macroeconomics and Growth Team

January 2013 
Policy Research Working Paper 6300

\begin{abstract}
In the aftermath of its long-standing civil war, Sri Lanka is keen to reap the social and economic benefits of peace. Even in the middle of civil conflict, the country was able to grow at rates that surpassed those of its neighbors and most developing countries. It is argued, then, that the peace dividend may bring about even higher rates of economic growth. Is this possible? And if so, under what conditions? To be sure, Sri Lanka's high growth rate in the past three decades did not come for free. It took an increasing effort of resource mobilization in the country, with a rise in national saving from 15 percent of gross domestic product in the mid-1970s to 25 percent in 2010. This rise in national saving was fundamentally fueled and sustained by the private sector. In the future, however, the private saving rate is likely to decline because the demographic transition experienced in the country is bound to produce higher old dependency rates in the next two decades. However, the public sector has much room for reducing its deficits and increasing public investment. Similarly, external investors are likely to encounter attractive and profitable investment projects in the coming years in a reformed
\end{abstract}

and peaceful environment. The government of Sri Lank has two goals regarding these issues. First, increasing public saving to 1.5 percent of gross domestic product by 2013; and second, increasing international investment in the country by letting the current account deficit increase to 4-5 percent of gross domestic product in the coming years. If these goals are achieved, what can be expected for growth of gross domestic product in the country? To answer this question, this paper presents a neoclassical growth model with endogenous private saving, calibrates it to fit the Sri Lankan economy, and simulates the behavior of growth rates of gross domestic product and related variables under different scenarios. In what the authors call the Reform Scenario, total factor productivity would increase from 1 to 1.75 percent per year. This would produce a gross domestic product growth rate of about 6.5 percent in the next 5 years, 4.6 percent by 2020 , and 3.5 percent by 2030 , the end of the simulation period. This robust growth performance would be supported at the beginning mostly by capital accumulation but later on mainly by productivity improvements.

This paper is a product of the Macroeconomics and Growth Team, Development Research Group. It is part of a larger effort by the World Bank to provide open access to its research and make a contribution to development policy discussions around the world. Policy Research Working Papers are also posted on the Web at http://econ.worldbank.org. The authors may be contacted at chevia@worldbank.org and nloayza@worldbank.org.

The Policy Research Working Paper Series disseminates the findings of work in progress to encourage the exchange of ideas about development issues. An objective of the series is to get the findings out quickly, even if the presentations are less than fully polished. The papers carry the names of the authors and should be cited accordingly. The findings, interpretations, and conclusions expressed in this paper are entirely those of the authors. They do not necessarily represent the views of the International Bank for Reconstruction and Development/World Bank and its affiliated organizations, or those of the Executive Directors of the World Bank or the governments they represent. 


\title{
Saving and Growth in Sri Lanka
}

\author{
Constantino Hevia and Norman Loayza* \\ World Bank
}

JEL: O40, O47, E21

Keywords: Economic growth, private saving, public saving, growth accounting, Sri Lanka

\footnotetext{
*Hevia: The World Bank and Universidad di Tella. Loayza: The World Bank. Sector Board: EPOL. We are grateful to Francis Rowe, Brian Pinto, and Luis Servén for guidance and support for this project. We thank Mona Prasad and Susana Lundstrom for data and related advice. Tomoko Wada provided excellent research assistance.
} 


\section{Introduction}

In the aftermath of its long-standing civil war, Sri Lanka is keen to reap the social and economic benefits of peace. Even in the middle of civil conflict, the country was able to grow at rates that surpassed those of its neighbors and most developing countries (see Figure 1). It is argued that the peace dividend may bring about even higher rates of economic growth. Is this possible? And if so, under what conditions? The key to answer these questions resides in the interaction between Sri Lanka's potential for capital accumulation and the likelihood of strong productivity improvements in the coming years.

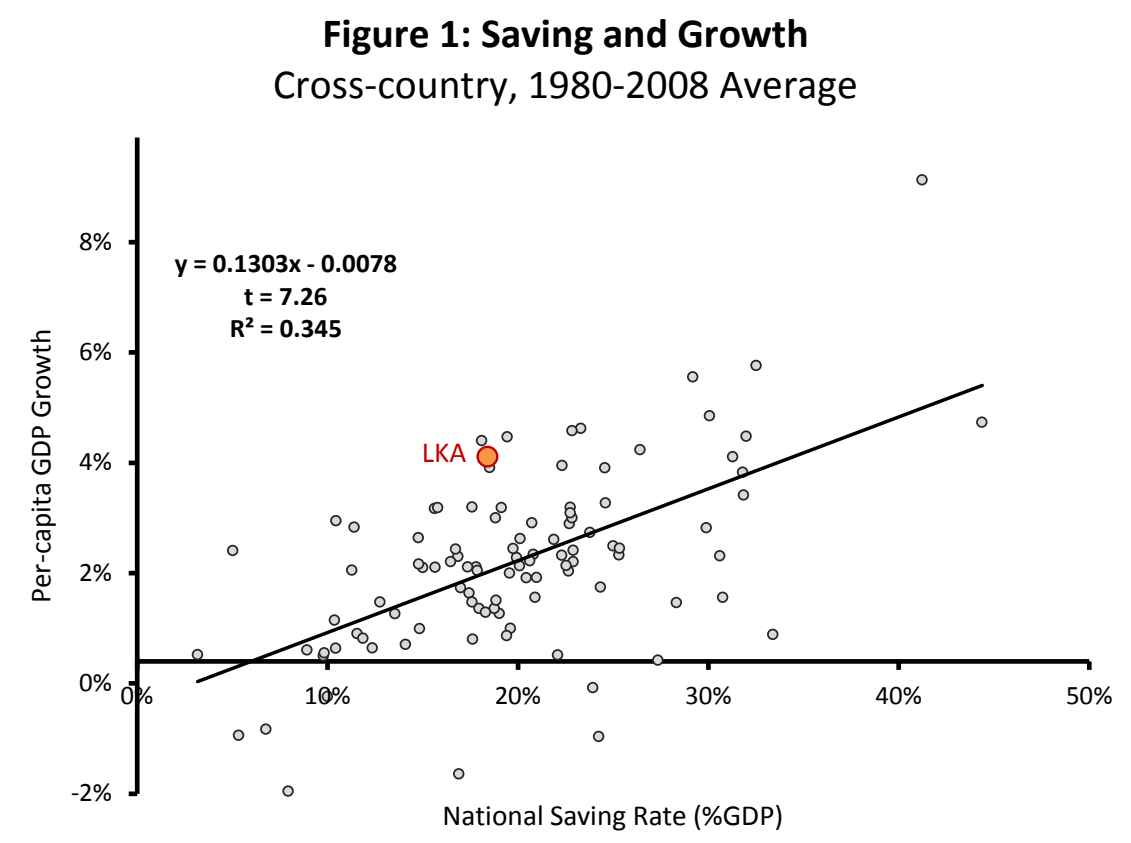

Goals to increase economic growth usually refer back to concerns for raising national saving. This is at least partially warranted because the relationship between national saving and economic growth is quantitatively strong and robust to different types of data and methodologies (see Mankiw et al. 1992, Attanasio et al. 2000, and Banerjee and Duflo 2005, among many others). Countries that have high saving rates for long periods of time tend to experience large and sustained economic growth (see Figure 1). A prime example is the experience of the developing countries in East Asia, such as China, Singapore, Korea, Malaysia, Thailand, and Taiwan, China (see Young 1995). 
To be sure, some of the relationship between growth and saving reflects the positive impact that higher income has on improved saving (see Loayza et al. 2000). However, no less important is the causality that runs from higher saving to larger growth, where the mechanism resides on the well-known process of capital accumulation. Improved national saving provides the funds to take advantage of more and larger investment opportunities. This, in turn, increases the capital stock, which effectively used for economic production contributes to higher output growth. Although in theory domestic investment does not have to be supported by national saving, in practice the connection between the two is quite close (see Aizenman, Pinto, and Radziwill, 2007). This is especially true in the long run, when external sources of funds can be tapped only in a restricted manner: large current account deficits cannot be sustained indefinitely. This is exemplified by the strong relationship between the average saving and investment rates across countries in the last three decades, as depicted in Figure 2.

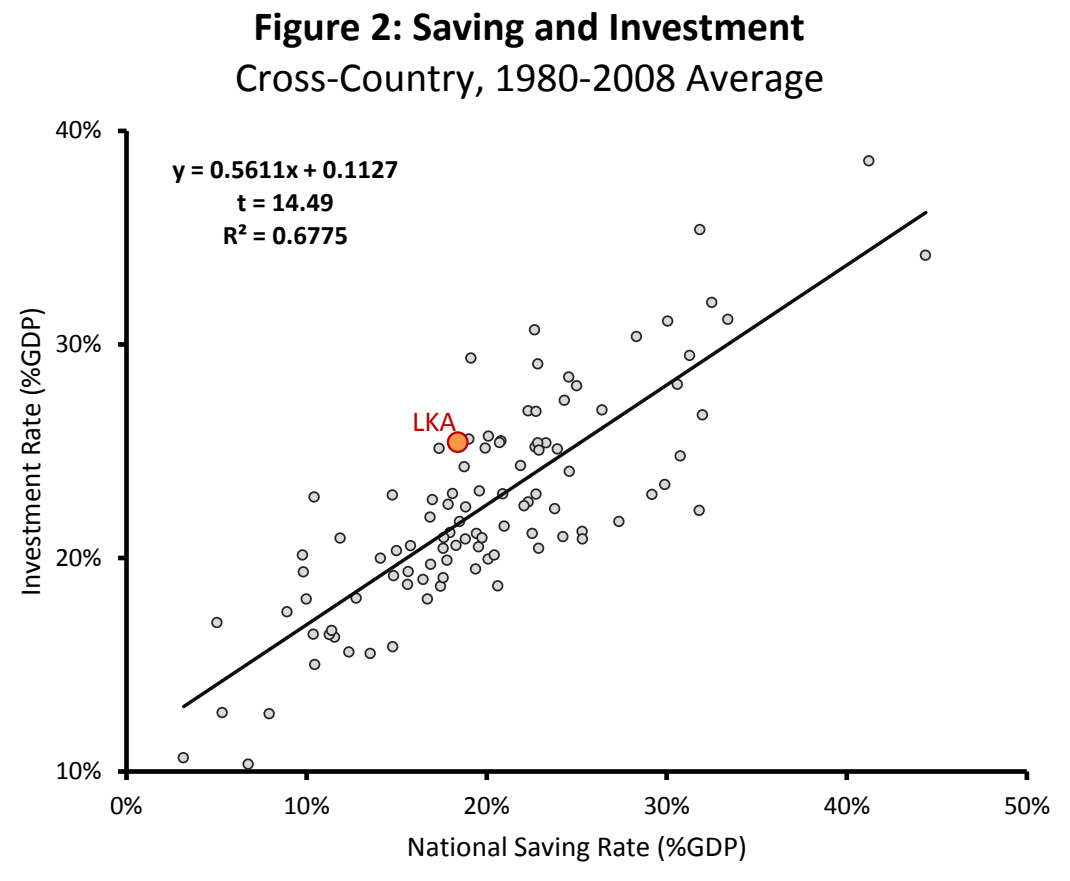

In Sri Lanka, as in most other countries, capital accumulation depends crucially on the country's ability to save. National saving in Sri Lanka increased from below 15\% of GDP in the mid-1970s to about 25\% of GDP in 2010 (see Figure 3). This is a remarkable trend. However, it is the private sector which has supported this positive trend, while the public sector has decreased its savings since the mid-1980s, even dissaving since the 1990s. 
Figure 3: National, Private, and Public Saving in Sri Lanka

$1975-2010$

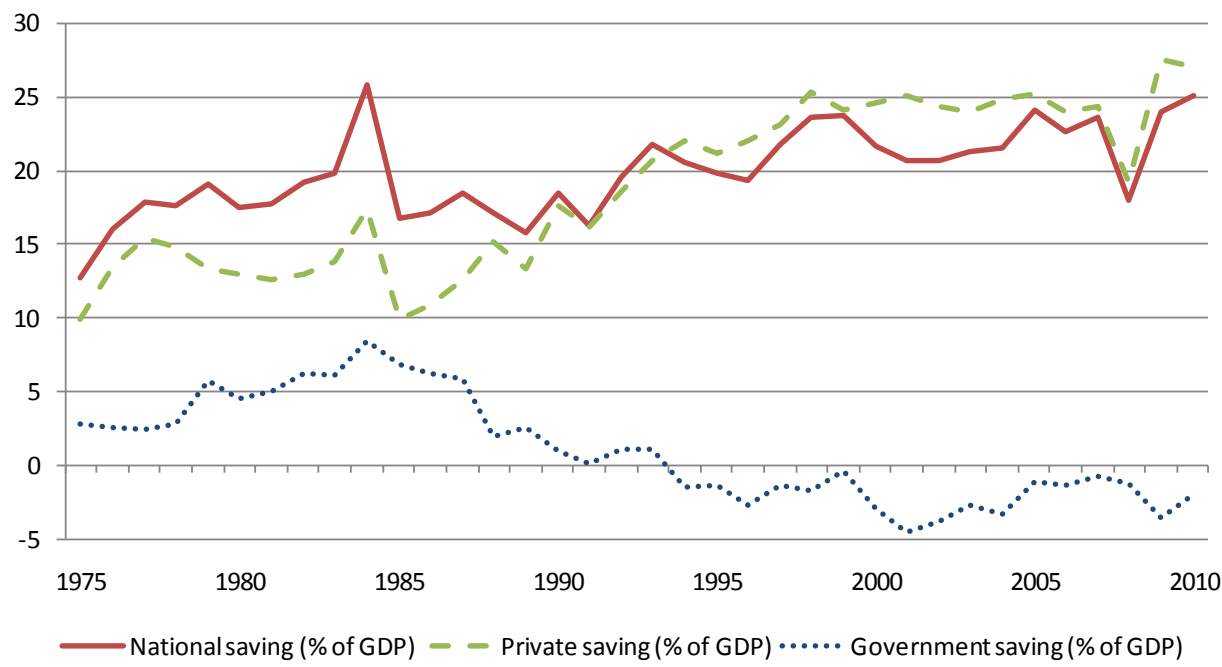

Most national savings in Sri Lanka have originated from income inside the country. From the mid-1980s, domestic savings have been $75-80 \%$ of national saving (see Figure 4). A non-negligible share, however, has originated from income from abroad. Official grants were the majority of foreign income in the late 1970s and early 1980s, while workers' remittances increased from almost nothing in the mid 1970 s to $5 \%$ of GDP by early 1980 s. Since then, workers' remittances have remained in the range of 5 to $7 \%$ of GDP, explaining the majority of the difference between national and domestic saving.

Figure 4: National and Domestic Saving in Sri Lanka $1975-2010$

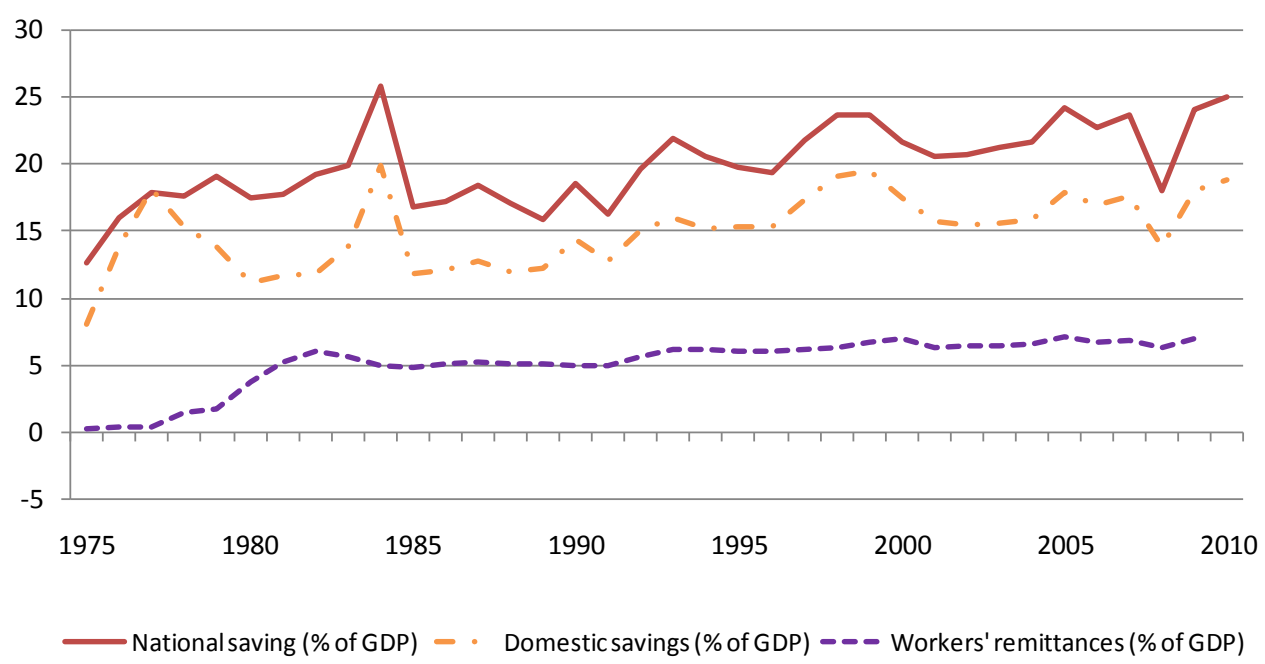


In Sri Lanka, the domestic investment rate has been traditionally higher than the national saving rate, with a resulting sustained current account deficit (see Figure 5). Except for a few years in the early 1980s when the current account deficit jumped as high as $16 \%$ of GDP, it has remained at around or below $5 \%$ of GDP. The inflow of resources from abroad has helped the country maintain higher rates of growth than its national saving rate alone would have predicted (see Figure 1). Although foreign financing is expected to continue in the future, it is likely to remain within the confines of its historical rates with respect to economy's size.

\section{Figure 5: National, Private and Public Saving in Sri Lanka}

1975-2010

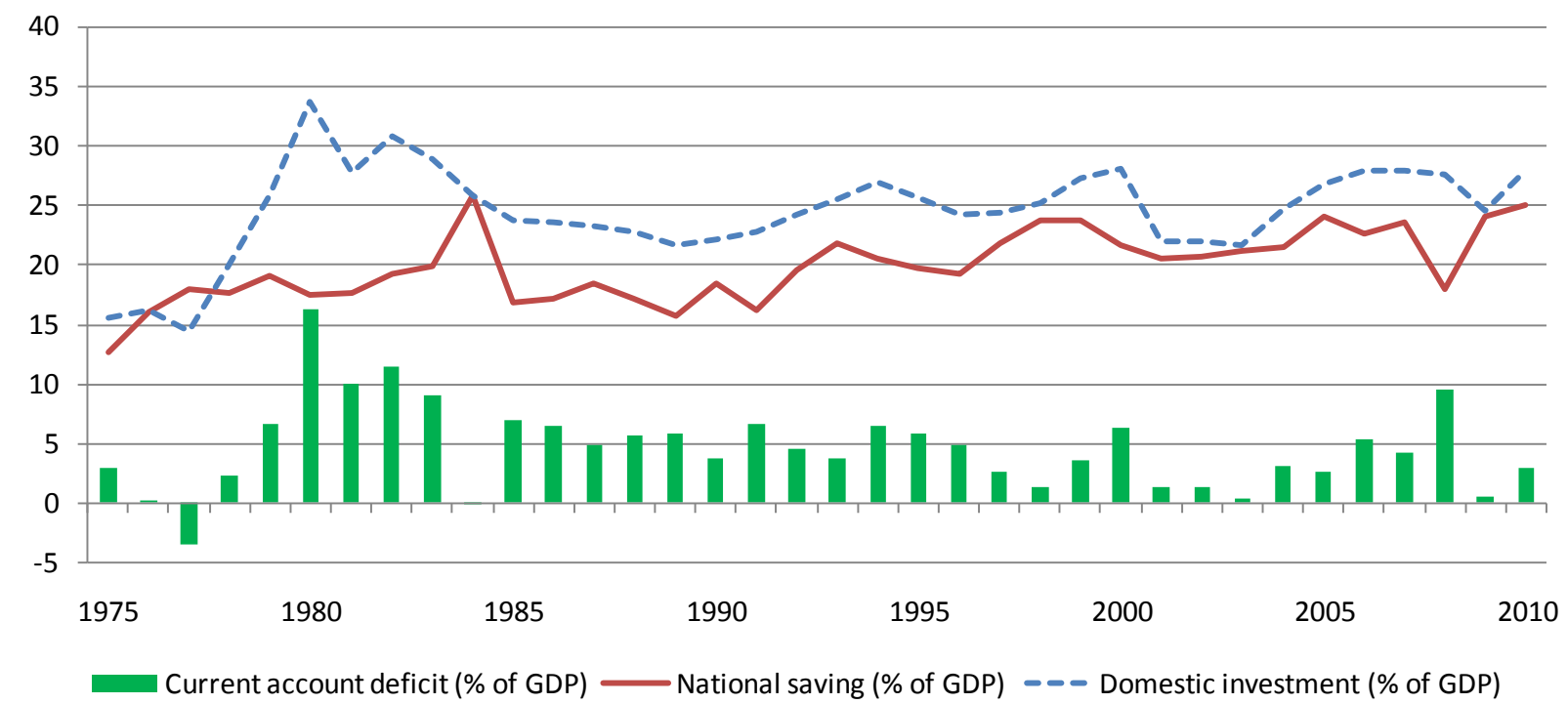

The links in the relationship between saving and growth are not mechanical but depend on the quality of the financial system and public institutions in general. Without an efficient financial system, the best investment opportunities will not be matched with the available saving (see Levine 2005). Likewise, without proper public institutions (that guarantee macroeconomic stability and contract enforcement, for instance), accumulated capital may remain idle or ineffectively used (see Hall and Jones 1999 and Easterly and Levine 2001). This points out to the crucial importance of the efficiency or productivity with which physical capital, human capital, and labor are used in the production process. The growth of factor productivity is what in the end determines whether a saving and investment effort will result (or not) in improved economic growth. 
The objective of this study is to illustrate the mechanisms linking national saving and economic growth in Sri Lanka. Moreover, recognizing that private saving is not directly a policy lever but an endogenous variable, the study will assess the role and potential contribution of public saving in generating growth. We will do this through a simple theoretical model, calibrated to fit the Sri Lankan economy, and simulated to explore different potential scenarios. Our goal is to understand the two-way connection between saving and growth and the possibilities and limits of a saving-based growth agenda, in the context of Sri Lanka's economy.

Optimality of saving behavior can be posed from different angles. The most common in the academic literature is the perspective of optimal saving as the behavior that maximizes a consumer welfare function. This, however, may be too abstract for the needs and objectives of policy practitioners. For this reason, we pose the problem of optimal saving from the perspective of financing a given rate of economic growth while simultaneously achieving external sustainability.

The paper proceeds as follows. First, we present a simple model, constructed with the purpose of understanding the necessary level of national and public saving to generate a given rate of economic growth (that is, following the optimality perspective described above). The model is neoclassical in the sense that the factors of production -labor and physical and human capital-are subject to decreasing marginal returns. Had we used instead an endogenous growth model with constant marginal returns to capital, changes in the rate of capital accumulation would have had permanent effects on long-run growth, a result not supported by the evidence (see Bernanke and Gürkaynak 2002, Caselli 2005, Easterly and Levine 2001, and Hall and Jones 1999). Moreover, methodologically it is more straightforward to examine both the limitations of a saving-based growth agenda and the role of productivity improvements in the context of the neoclassical than the endogenous growth model.

Second, we calibrate the model to Sri Lanka's economy, using parameters and relationships obtained in the received literature for the country. Third, using the calibrated model, we perform some simulations that clarify the relationship between public and national saving, productivity, and growth, allowing us to discuss policy options for improving economic growth in Sri Lanka. And fourth, we provide some concluding remarks, arguing that for the 
country to grow at rates comparable to those of the East Asian tiger economies, the public sector must contribute substantially to national saving, and institutional and economic reforms must lead to strong and persistent productivity improvements.

\section{A Simple Model}

We consider a model of an open economy with a single sector that produces a unique final good which we call gross domestic product (GDP) or, simply, output. The economy evolves in discrete time and each time period, denoted by an index $t$, represents one year.

The economy has access to a technology to produce output by combining capital and labor inputs according to the production function

$$
Y_{t}=A_{t} K_{t}^{\alpha} L_{t}^{1-\alpha}
$$

where $Y_{t}$ denotes output, $K_{t}$ is the stock of physical capital, $L_{t}$ denotes the labor input, $A_{t}$ is a measure of the level of total factor productivity of capital and labor (TFP), and the technology parameter $\alpha \in(0,1)$ measures the relative contribution of capital to the production of output-in an economy operating under perfect competition, $\alpha$ measures the share of output distributed as payments to capital.

We abstract from distributional issues and assume that all workers have the same level of human capital. Following Bils and Klenow (2000) and Hall and Jones (1999), we assume that each worker has been trained with $z_{t}$ years of schooling, which deliver a productivity of $\exp \left(\phi z_{t}\right)$ efficiency units of labor per worker, where $\exp (\cdot)$ denotes the exponential function. Thus, $\phi z_{t}$ measures the relative efficiency of a worker with $z_{t}$ years of schooling relative to one with no schooling. Thus, if we let $E_{t}$ denote the working-age population, effective aggregate labor supply is given by

$$
L_{t}=\exp \left(\phi z_{t}\right) E_{t}
$$

Capital depreciates at a constant rate $\delta$ per year, but can be augmented through investment. Namely, the stock of capital evolves according to 


$$
K_{t+1}=(1-\delta) K_{t}+I_{t}
$$

where $I_{t}$ denotes aggregate investment.

Abstracting from valuation changes, the current account deficit at period $t, C A D_{t}$, is defined as the change in net foreign liabilities of the whole economy, or

$$
C A D_{t} \equiv B_{t+1}-B_{t}=r B_{t}+C_{t}+G_{t}+I_{t}-Y_{t}-T R_{t}
$$

where $B_{t}$ is the stock of net foreign liabilities due at period $t ; r$ is the world interest rate, assumed constant for simplicity; $C_{t}$ denotes private consumption; $G_{t}$ denotes government consumption expenditures; and $T R_{t}$ denotes the flow of net external current transfers (worker remittances and official grants) that are not reflected as changes in the country's net foreign liabilities. ${ }^{1}$

If we let $S_{t}^{N}=Y_{t}+T R_{t}-r B_{t}-C_{t}-G_{t}$ denote aggregate national saving, the previous equation can be rearranged into the familiar investment-saving gap identity of an open economy,

$$
I_{t}=S_{t}^{N}+C A D_{t}
$$

That is, domestic investment $I_{t}$ can be financed through national saving or through foreign saving (i.e. through an increase in net foreign liabilities).

External solvency requires that the current value of foreign liabilities be no larger than the present value of net exports, and can be obtained by iterating forward on the current account identity (4); namely,

$$
\sum_{j=0}^{\infty} \frac{1}{(1+r)^{j}}\left[Y_{t+j}+T R_{t+j}-I_{t+j}-C_{t+j}-G_{t+j}\right]=(1+r) B_{t}
$$

This solvency condition imposes certain assumptions about the functioning of international capital markets that are difficult to reconcile with the experience of emerging market economies. In particular, it fails to capture the financial frictions that are pervasive in developing countries. For this reason, we follow Milesi-Ferretti and Razin (1996) and impose a

\footnotetext{
${ }^{1}$ Worker remittances and other transfers from abroad are quite important for Sri Lanka, representing over $5 \%$ of GDP in the last decade.
} 
sufficient condition for current account sustainability that is also appealing in terms of its realism.

In Hevia and Loayza (2011) we assumed that the economy was required to maintain the ratio of net foreign liabilities to GDP constant. For the case of Sri Lanka, this might be too strong an assumption, given expectations of larger foreign participation in domestic investment during the next years. We thus assume that the ratio of net foreign liabilities to GDP is allowed to evolve through time according to,

$$
B_{t} / Y_{t}=\beta_{t}
$$

where $\left\{\beta_{t}\right\}$ is an exogenous sequence. For example, if $\beta_{t}$ increases for a number of years and then becomes constant, the economy is increasing its foreign indebtedness and, thus, the foreign participation in domestic capital formation. On the other hand, if $\beta_{t}$ decreases through time, the economy is reducing its foreign indebtedness. The proposed modification to the solvency condition is a reduced form approach aimed to capture the reluctance of foreigners to lend money when the level of debt is sufficiently high, or because the government wants to maintain a safe level of foreign borrowing relative to output.

Using the definition of the current account, condition (6) imposes the following restriction on the current account deficit as a fraction of gross domestic output,

$$
\frac{C A D_{t}}{Y_{t}}=\frac{B_{t+1}}{Y_{t+1}} \frac{Y_{t+1}}{Y_{t}}-\frac{B_{t}}{Y_{t}}=\beta_{t+1} \frac{Y_{t+1}}{Y_{t}}-\beta_{t} .
$$

That is, the ratio of the current account deficit to the value of output depends upon the net foreign liabilities as a fraction of GDP at times $t$ and $t+1$, and on the growth rate of output, $Y_{t+1} / Y_{t}$

For quantitative purposes, we find it convenient to rewrite all previous equation in per capita terms. To that end, let $N_{t}$ denote total population at time $t$ and, for any aggregate variable $X_{t}$, let $x_{t}=X_{t} / N_{t}$ denote the corresponding variable in per-capita terms. Thus, introducing the definition of effective labor (2) into the production function (1) and dividing the resulting expression by $N_{t}$ gives the following expression for GDP per capita 


$$
y_{t}=A_{t} k_{t}^{\alpha}\left(\exp \left(\phi z_{t}\right) e_{t}\right)^{1-\alpha} .
$$

In general, the labor force variable $e_{t}=E_{t} / N_{t}$ varies through time as the demographic characteristics of the economy changes.

Following the same approach, we write the equilibrium equations (3), (5), and (7) in percapita terms as

$$
\begin{gathered}
k_{t+1} \Gamma_{N, t+1}=(1-\delta) k_{t}+i_{t}, \\
i_{t}=s_{t}^{N}+\operatorname{cad}_{t}, \\
\frac{\operatorname{cad}_{t}}{y_{t}}=\beta_{t+1} \Gamma_{y, t+1} \Gamma_{N, t+1}-\beta_{t} .
\end{gathered}
$$

Here and throughout the paper, expressions like $\Gamma_{x, t+1}=x_{t+1} / x_{t}$ denote the gross growth rate of any variable $x_{t}$ between periods $t$ and $t+1$.

We now use the previous equations to write a condition that relates national saving and growth. First, we use the production function in equation (8) at periods $t$ and $t+1$ to write the gross growth rate in output per capita as

$$
\Gamma_{y, t+1}=\Gamma_{A, t+1} \Gamma_{k, t+1}^{\alpha}\left(\exp \left[\phi\left(z_{t+1}-z_{t}\right)\right] \Gamma_{e, t+1}\right)^{1-\alpha}
$$

That is, the growth rate of output per capita $\Gamma_{y, t+1}$ depends upon the growth rate of productivity $\Gamma_{A, t+1}$, the growth rate of the stock of capital $\Gamma_{k, t+1}$, the growth rate of human capital $\exp \left[\phi\left(z_{t+1}-z_{t}\right)\right]$, and the growth rate of the labor force $\Gamma_{e, t+1}$.

Second, introducing the investment-saving equation (10) into the capital accumulation equation (9) and rearranging gives

$$
\Gamma_{k, t+1} \Gamma_{N, t+1}=1-\delta+\frac{i_{t}}{y_{t}} \frac{y_{t}}{k_{t}}=1-\delta+\left(\frac{s_{t}^{N}+c a d_{t}}{y_{t}}\right) \frac{y_{t}}{k_{t}} .
$$

This equation describes the growth rate of the stock of capital per person as a function of the growth rate of the population $\Gamma_{N, t+1}$, the depreciation rate $\delta$, the national saving ratio with respect to GDP $s_{t}^{N} / y_{t}$, the current account deficit as a fraction of GDP $c a d_{t} / y_{t}$, and the degree of capital intensity in the economy $k_{t} / y_{t}$. 
Imposing the sustainability condition (11) into the last equation, the evolution of the stock of capital becomes

$$
\Gamma_{k, t+1} \Gamma_{N, t+1}=1-\delta+\left\{\sigma_{t}+\beta_{t+1} \Gamma_{y, t+1} \Gamma_{N, t+1}-\beta_{t}\right\} \frac{y_{t}}{k_{t}}
$$

where $\sigma_{t}=s_{t}^{N} / y_{t}$ denotes the national saving ratio with respect to GDP. ${ }^{2}$

Finally, introducing (13) into the output growth equation (12) delivers an equation that links the growth rate of output per capita to the national saving ratio $\sigma_{t}$, the growth rate of productivity $\Gamma_{A t}$, the growth rate of the population $\Gamma_{N t}$, the growth rate of the labor force $\Gamma_{e t}$, the growth rate in human capital $\exp \left[\phi\left(z_{t+1}-z_{t}\right)\right]$, and the capital-output ratio $k_{t} / y_{t}$,

$$
\Gamma_{y, t+1}=\left[\frac{1-\delta+\left\{\sigma_{t}+\beta_{t+1} \Gamma_{y, t+1} \Gamma_{N, t+1}-\beta_{t}\right\} \frac{y_{t}}{k_{t}}}{\Gamma_{N, t+1}}\right]^{\alpha} \Gamma_{A, t+1}\left(\exp \left[\phi\left(z_{t+1}-z_{t}\right)\right] \Gamma_{e, t+1}\right)^{1-\alpha}
$$

Condition (14) is the key equation that associates the growth rate of GDP per capita with the national saving ratio $\sigma_{t}$.

\subsection{Endogenous Private Saving}

In the previous section we derived an equation that associates national saving with the growth rate of GDP per capita. The question remains, of course, as to how to actually achieve the desired level of national saving given the policy instruments that the government has access to. Any attempt to answer this question faces the immediate fact that private saving is not invariant to policy interventions and to the structural characteristics of the economy, like the ratio of old-age and young age population over working-age population, the level and growth rate of income, and the level of public saving-capturing Ricardian effects on aggregate saving. A standard way of tackling this problem is to posit a model of intertemporal consumption choice and evaluate how different policies affect the level of private saving. This approach,

\footnotetext{
${ }^{2}$ Note that $s_{t}^{N} / y_{t}$ is neither the national saving rate nor the domestic saving rate as defined in the national accounts statistics. The national saving rate is defined as $s_{t}^{N} / y_{t}^{N}$ where $y_{t}^{N}=y_{t}-r b_{t}+t r_{t}$ is national disposable income (per capita), whereas the domestic saving rate is defined as $s_{t}^{D} / y_{t}$, where $s_{t}^{D}=y_{t}-c_{t}-g_{t}$ is domestic saving (per capita).
} 
however, is not free of problems and requires a detailed description of the economic environment, preferences, the set of policy instruments available to the government, and how expectations about future events are formed. To simplify matters and to keep the discussion as straightforward as possible, we follow a different route and consider a reduced form equation for the private saving rate. Borrowing from Loayza et al. (2000), we assume that the private saving rate depends on its own lagged value, on the old-age and young-age dependency rates, on the level and growth rates of GDP, and on public saving. Loayza et al. (2000) contain a detailed discussion about these determinants of saving and provide estimates of the aforementioned reduced form private saving equation based on a large cross-section, timeseries dataset.

We decompose the national saving ratio as the sum of the private and public saving ratios, $\sigma_{t}^{p}$ and $\sigma_{t}^{g}$ respectively, or

$$
\sigma_{t}=\sigma_{t}^{p}+\sigma_{t}^{g}
$$

The functional form of the private saving rate at time $t$ is assumed to be,

$$
\sigma_{t}^{p}=\zeta_{1} \sigma_{t-1}^{p}+\zeta_{2} \sigma_{t}^{g}+\zeta_{3} \log y_{t}+\zeta_{4} \log y_{t-1}+\zeta_{5} o d_{t}+\zeta_{6} y d_{t}+\eta,
$$

where $o d_{t}$ denotes the old-age dependency rate, $y d_{t}$ is the young-age dependency rate, and $\zeta_{i}, i=1, \ldots, 6$ and $\eta$ are constants. Thus, the private saving ratio depends on its own lagged value, on the public saving rate, on the current and lagged (log) levels of GDP per-capita, and the old-age and young age dependency rates. The parameters $\zeta_{i}, i=1, \ldots, 6$ are set according to Loayza, Schmidt-Hebbel, and Servén's estimates. The constant $\eta$ is a country specific fixed effect which will be removed by differencing the previous equation. In particular, lagging the previous equation and taking the difference gives

$$
\sigma_{t}^{p}=\sigma_{t-1}^{p}+\zeta_{1} \Delta \sigma_{t-1}^{p}+\zeta_{2} \Delta \sigma_{t}^{g}+\zeta_{3} \Delta \log y_{t}+\zeta_{4} \Delta \log y_{t-1}+\zeta_{5} \Delta o d_{t}+\zeta_{6} \Delta y d_{t} .
$$

Inserting this equation into (15) gives the national saving ratio at time $t$ as a function of the public saving ratio at time $t$, the structural characteristics of the economy, and lagged private saving ratios, 


$$
\sigma_{t}=\sigma_{t-1}^{p}+\zeta_{1} \Delta \sigma_{t-1}^{p}+\zeta_{2} \Delta \sigma_{t}^{g}+\zeta_{3} \Delta \log y_{t}+\zeta_{4} \Delta \log y_{t-1}+\zeta_{5} \Delta o d_{t}+\zeta_{6} \Delta y d_{t}+\sigma_{t}^{g}
$$

In the quantitative section of the paper we perform two sets of experiments. In the first experiment, we find the public saving rate required to achieve certain growth rate of GDP percapita recognizing that the private saving rate evolves endogenously as a function of the characteristics of the economy. In the second experiment, we fix a path for the public saving ratio and let the private saving ratio and GDP per capita evolve endogenously through time. These exercises are described in detail after we discuss the calibration of the parameters of the model and the estimation of the demographic characteristics of the economy based on data from Sri Lanka.

\subsection{Calibration}

Before we can use the model to simulate potential scenarios, we need to calibrate it with information specifically related to Sri Lanka's economy. The main pieces of information are the following,

- The current capital-output ratio: $k_{t} / y_{t}=1.314$. This is the ratio estimated for the year 2010, using a perpetual inventory method to accumulate investment in order to produce a measure of the capital stock. Given the war-related destruction of factories, transport facilities, buildings, and other forms of capital, we cannot assume a fixed and relatively low depreciation rate $(0.04-0.08$, as in most of the literature). We allow the depreciation rate to vary and, in order to identify it, assume a constant rate of TFP growth equal to 0.0107 , the average reported for Sri Lanka in the last decades by Jorgenson and Vu (2005), Collins (2007), and Son (2010). ${ }^{3}$

- The capital share in output: $\alpha=0.35$. This is the average across countries that Bernanke and Gürkaynak (2002) obtain using adjusted factor payment data from national accounts. There is no comparable Sri Lanka-specific estimate for the capital share.

- The annual capital depreciation rate: $\delta=0.08$. This is the depreciation rate used in

${ }^{3}$ On the importance of considering a different depreciation rate for Sri Lanka when estimating the capital stock, see Duma (2007). 
Klenow and Rodríguez-Clare (2005) in their chapter of the Handbook of Economic Growth. It is a bit larger than the depreciation rate assumed in other cross-country studies (e.g., 0.06 in Caselli, 2005). We use this higher rate because it is similar to the average depreciation rate for Sri Lanka in the last few years (after the civil war ended) as obtained in the process of estimating the capital stock (see above).

- The annual growth rate of the labor force, $\Gamma_{E t}$, is obtained from the future demographic projections for Sri Lanka population aged 15-70 years old, presented in United Nations (2011), World Population Prospects: The 2008 Revision.

- The annual increase in education: $\left(z_{t+1}-z_{t}\right)=0.05104$. Education is proxied by the average number of schooling years in the adult population. This estimate for the annual increase in schooling is taken from the Barro and Lee (2010) dataset and corresponds to the average annual change for the period 1990-2010.

- The annual rate of return to education: $\phi=0.07$. This rate of return is used in Bernake and Gurkaynak (2001) and Collins (2007) in their growth accounting exercises, which also consider the average number of schooling years in the adult population as the proxy for education (and human capital in general).

- The ratio of net foreign liabilities to GDP, $\beta_{t}$, is assumed to rise from its current value of 0.45 to 0.60 gradually in 15 years. This approximately corresponds to the government's target of a current account deficit of 4-5\% of GDP over the next 5 years and declining afterwards. The current ratio of net foreign liabilities to GDP is obtained from updating the Lane and Milesi-Ferreti (2007) database. Official "international investment position" for Sri Lanka is not available in the IMF's Balance of Payments Statistics.

- Productivity Scenarios. A key parameter in the simulations presented below is the rate of growth of total factor productivity, $\Gamma_{A t}$. The available estimates for TFP growth in Sri Lanka indicate an average of around 1\% growth per year in the last few decades (see Jorgenson and Vu, 2005, Collins, 2007, and Son, 2010). We consider this TFP growth rate in a first scenario, which we call "Continuity Scenario." If Sri Lanka is able to reform its economy and institutions along the lines proposed in 
recent government plans, the country's TFP growth rate is likely to increase substantially. For the second scenario, we use the average TFP growth rate of the top quarter of countries in a worldwide sample as a benchmark for what is possible under economic reform (see Bernanke and Gürkaynak, 2002). This is approximately equal to $1.75 \%$ per year, rate which we use for what we call the "Reform Scenario." Finally, if Sri Lanka is able to conduct all of its intended reforms and also benefit from a positive international environment, its TFP growth rate could increase even further. We use the rate of $2.5 \%$ per year in an "Optimistic Scenario." This is clearly an upper limit, which very few countries have been able to obtain in a sustainable manner.

\section{Simulations}

Using the model developed above and the calibration parameters, we can perform different numerical exercises to give answers and insights regarding the link between saving, investment, productivity, and growth. We perform two basic, complementary simulations. The first one is designed to measure the saving rates that are required to finance a given rate of economic growth. This rate is set to $7.2 \%$ of GDP per capita growth for the period 2011-2015. This corresponds closely to the government's target GDP growth rate of $8 \%$ for the next 5 years. After this period, economic growth is determined by the dynamics of the model. This target growth rate is clearly ambitious from historical and cross-country perspectives for Sri Lanka. The second simulation changes perspectives and asks what economic growth rates can be financed if the public saving rate is increased to a given level. In accordance to government plans, the public saving rate is assumed to increase gradually from its current level of - $2 \%$ of GDP to $1.5 \%$ by 2013 , and stay constant from then onwards. This implies a reduction in the government deficit to 5\% of GDP and an increase in public investment to 6.5\% of GDP by 2013. In both simulations, private saving is allowed to change endogenously in response to changes in public saving, demographic characteristics, and income growth.

Both simulations are dynamic in the sense that they follow the evolution of the economy for an extended period of time, chosen to be 20 years in our case. Also in both cases, 
we compute the corresponding Solow growth decomposition in order to understand the role played by factor accumulation and productivity advances in the process of economic growth. As mentioned in the previous section, the simulations are performed under three scenarios regarding the behavior of total factor productivity. TFP growth is assumed to be $1 \%, 1.75 \%$, $2.5 \%$, and the corresponding scenarios are labeled, Continuity, Reform, and Optimistic, respectively. The basic simulation results are presented in Figures 6-8. In each of them, the upper panel corresponds to the simulation where the growth rate of GDP per worker is the target; and, conversely, the lower panel shows the simulation where the public saving rate is set to a given level. In turn, in each panel we show 3 graphs: the first contains the projected national, public, and private saving rates (with respect to GDP) annually for the period 20102030; the second shows the projected annual per capita and aggregate GDP growth rates for the same period; and the third presents a Solow growth decomposition for the years 20112016, showing the percentage contributions of physical capital accumulation, total factor productivity, and labor (including human capital and labor force).

We first discuss the Continuity and Optimistic Scenarios to highlight how the savinggrowth relationship changes as productivity growth differs radically. We then present the Reform Scenario. We do it in greater depth than in the previous two cases because, in our perspective, it represents the most reasonable situation under a feasible set of international conditions and, most importantly, internal reforms.

Let us then start with the Continuity Scenario (Figure 6). The first simulation (upper panel) shows that, in the absence of a substantial improvement in TFP growth, the demands on capital accumulation to attain the goal of $7.2 \%$ GDP per capita growth (8\% GDP growth) in the next 5 years are excessively large. In fact, as the growth decomposition indicates, more than $80 \%$ of GDP per capita growth would have to be supported by physical capital accumulation. The national saving rate would have to increase enormously from $25 \%$ to $50 \%$ of GDP, requiring a rise in public saving to over $30 \%$ of GDP and even further in the course of the 20 -year horizon. The private saving rate would decrease by more than half, in part as a reaction to the large increase in the public saving rate.

The second simulation shows that if the public saving rate is increased to $1.5 \%$ of GDP, 
GDP growth would be above $6 \%$ only in the first years and then decrease gradually to about $4.5 \%$ by 2015 and a bit over $2 \%$ by 2030 . The lion share of the contribution to GDP growth $(76 \%)$ in the next five years would be given by capital accumulation. Given the impulse of public saving, the national saving rate would increase and remain above its current value for the next 7-8 years but would then decrease following the declining trend of private saving. Continuity in TFP growth, thus, implies a rate of economic growth that, although respectable by international standards, is far below the ambitious targets for the country. 


\section{Figure 6. Continuity Scenario}

TFP Growth Rate $=1 \%$
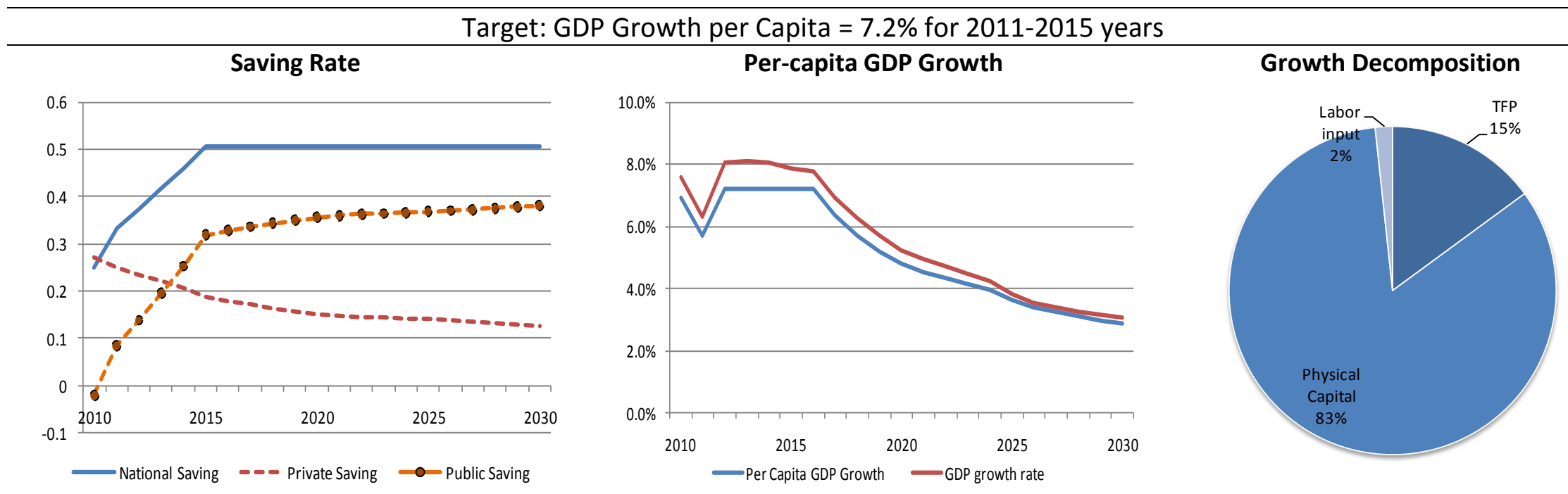

Target: Public Saving / GDP $=1.5 \%$ by 2013

Saving Rate

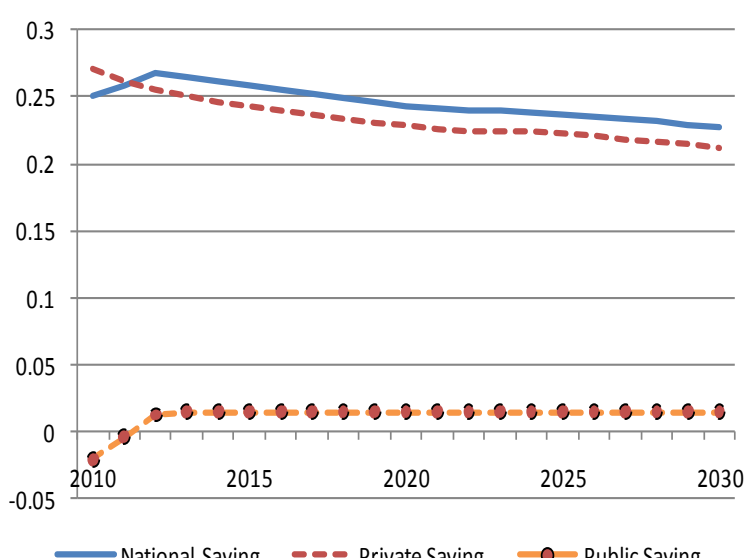

National Saving - - - Private Saving o- Public Saving

\section{Per-capita GDP Growth}

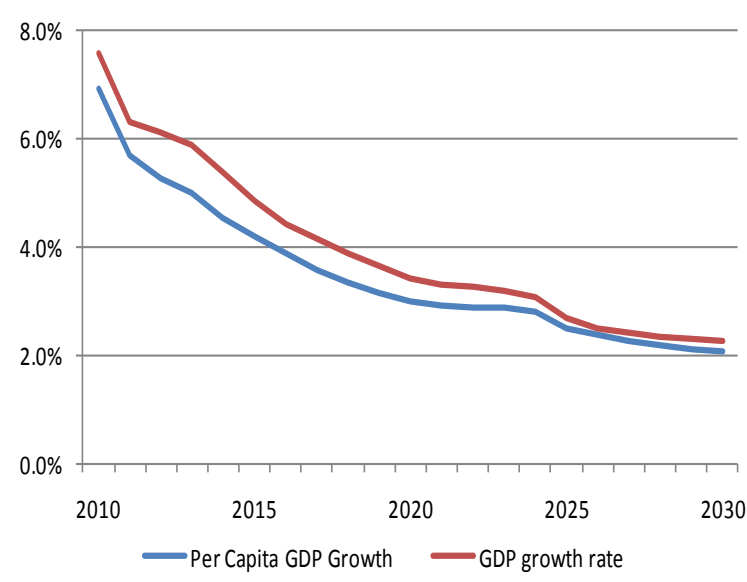

Growth Decomposition

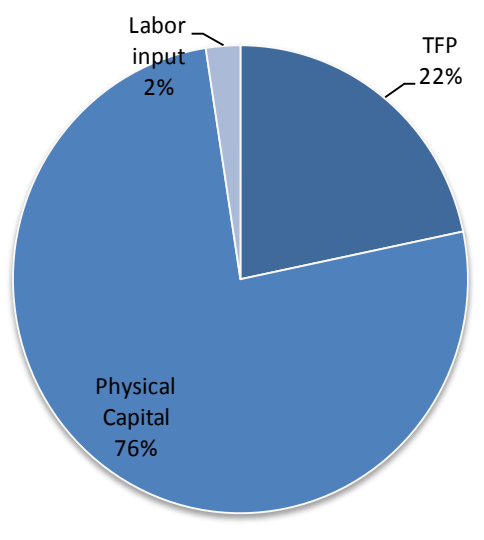


In the other extreme, let us consider the Optimistic Scenario, where TFP grows at a $2.5 \%$ rate (Figure 7). According to the first simulation (upper panel), in order to finance a 7.2\% GDP growth per capita (8\% GDP growth) in the next 5 years, national saving would need to rise from 25 to $33 \%$ of GDP. In turn, this would require an increase in public saving to almost $10 \%$ of GDP by 2015 . This would entail a strong effort, but a feasible one at that. As the Solow growth decomposition shows, now TFP would contribute about 35\% to GDP per capita growth. The large impulse from TFP under this scenario relieves the pressure on capital accumulation substantially to attain the high target of economic growth.

The second simulation under the Optimistic Scenario indicates that, with a small improvement in public saving, GDP growth would average $8 \%$ in the next few years and stay over or around $7 \%$ for the next decade. Then, it would decline to about $5 \%$ by 2030 , the end of our simulation horizon. With the impulse of public saving, the national saving rate would increase to around $27 \%$ and private saving would decrease only slightly. As the Solow decomposition shows, the contribution of TFP growth would account for $37 \%$ of GDP growth in the next five years. 
Figure 7. Optimistic Scenario

TFP Growth Rate $=2.5 \%$
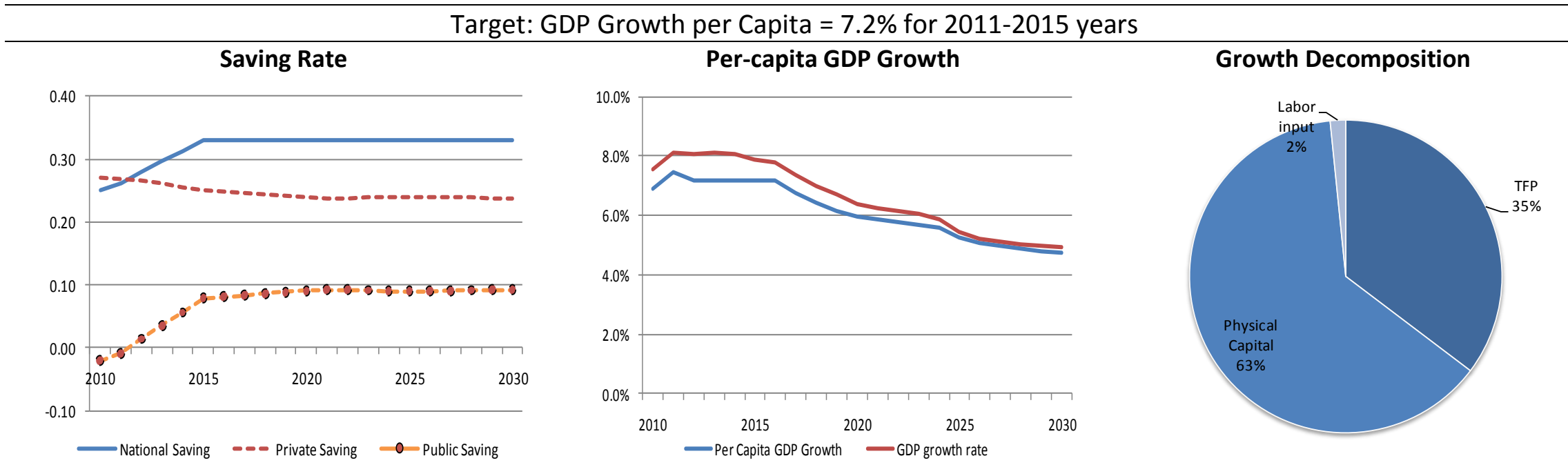

Target: Public Saving / GDP $=1.5 \%$ by 2013
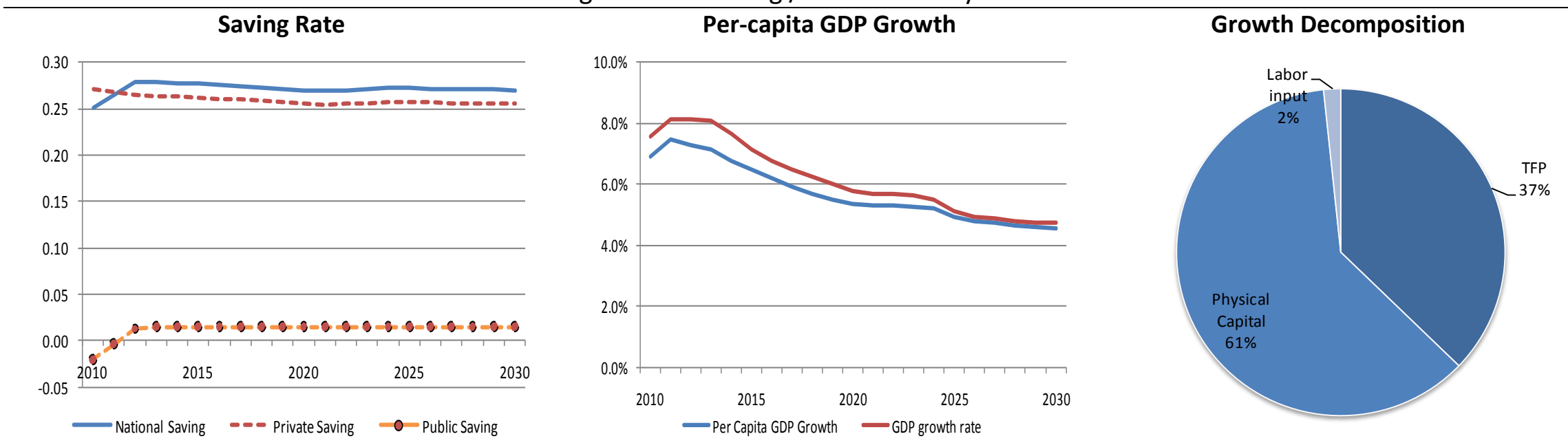
Let us now turn to the Reform Scenario, where TFP grows at a constant annual rate of $1.75 \%$ (Figure 8). The first simulation indicates that achieving a target of GDP per capita growth rate of $7.2 \%$ ( $8 \%$ GDP growth) in the next 5 years is indeed a difficult goal. It would require a jump in national saving from the current $25 \%$ to about $40 \%$ of GDP by 2015 , which in turn would require public saving to rise to $20 \%$ of GDP. The lion share of the contribution to growth would still need to come from capital accumulation, with only one-fourth coming from TFP growth. The required increase in national saving is substantial but has been observed in East Asian countries, most notably China. With free and endogenously determined private saving, however, the needed increase in national saving would have to be supported by an incredibly large expansion of public saving.

The second simulation under the Reform Scenario shows the behavior of GDP growth if public saving rate is increased to $1.5 \%$ of GDP by 2013 . Given TFP growth of $1.75 \%$, the growth rate of GDP would stay around $7 \%$ in the next 5 years and then gradually decline to $4.5 \%$ by 2020 and $3.5 \%$ by the end of the simulation period. Note that the difference between GDP growth and per capita GDP growth diminishes over time as population growth approaches zero.

Given the impulse in public saving, the national saving rate would increase from $25 \%$ to $27 \%$ by 2013 and then slowly decline back to $25 \%$ by 2030 . In turn, the private saving rate would follow a secular, though slow, decrease from $27 \%$ to $23 \%$ of GDP by the end of the simulation period. The trend in the private saving rate is due to the combination of three significant forces. The first is the increase in public saving, which would generate a small compensating decline in private saving. The second is the expected substantial rise in the old dependency rate, which would lead to a gradual fall in the private saving rate. (The expected decrease in the young dependency rate would have the opposite effect but its magnitude is much smaller.) The third is the rise in income related to GDP per capita growth; this would produce an increase in the private saving rate. It seems, then, that the first two, negative forces win over the last one, generating the decline, albeit slow in private saving rate. ${ }^{4}$

\footnotetext{
${ }^{4}$ The variation in the slope across simulations and scenarios is related to the projected change in public saving and GDP growth. The effect of demographic factors is constant across simulations and scenarios.
} 
Figure 8. Reform Scenario

TFP Growth Rate $=1.75 \%$

Target: GDP Growth per Capita $=7.2 \%$ for 2011-2015 years

\section{Saving Rate}

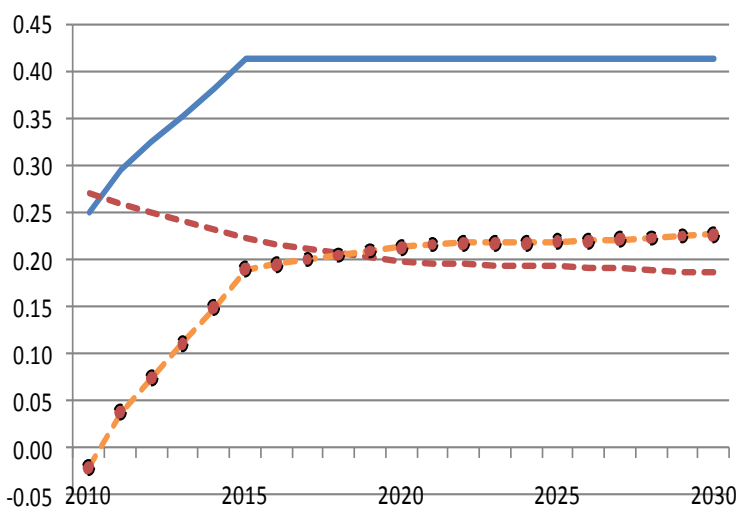

National Saving - - Private Saving $\quad$ - Public Saving

\section{Per-capita GDP Growth}

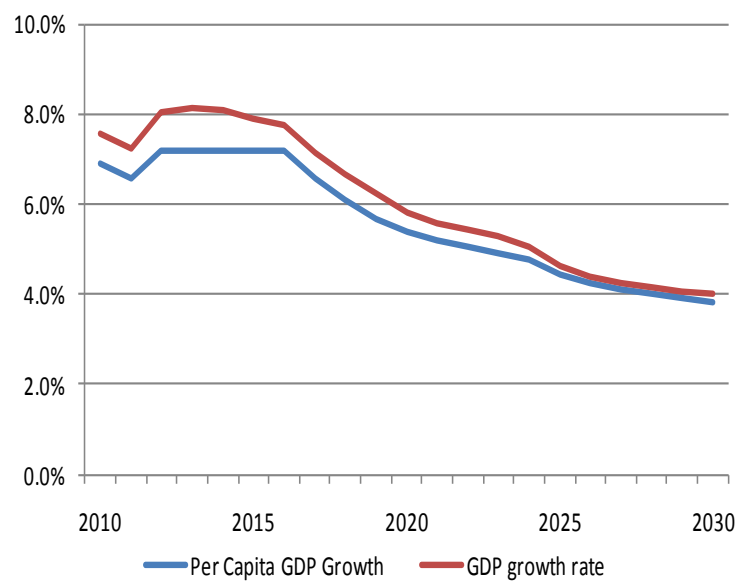

Growth Decomposition

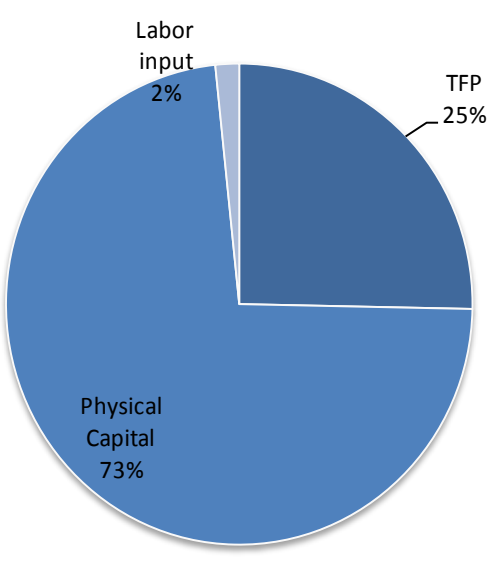

Target: Public Saving / GDP $=1.5 \%$ by 2013

Saving Rate

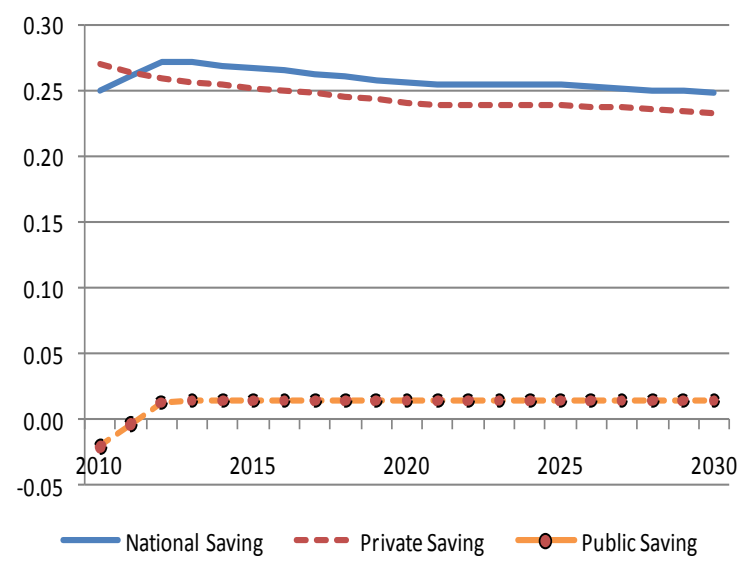

Per-capita GDP Growth

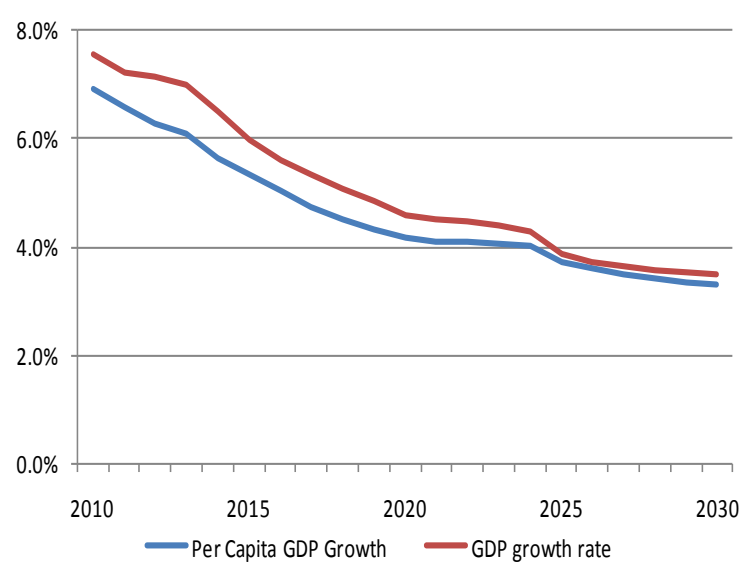

Growth Decomposition

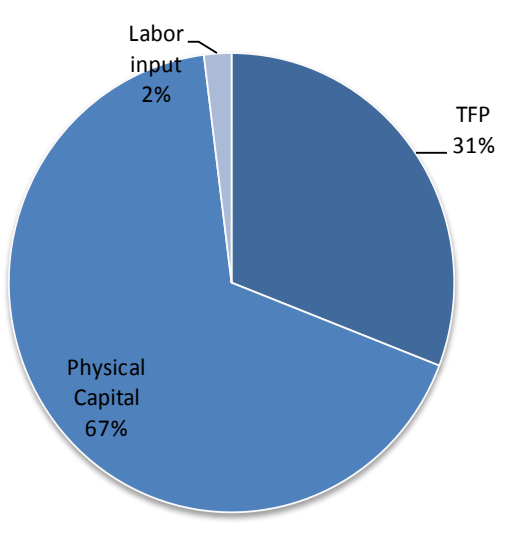


The behavior of the national saving rate would be followed to some extent by the rate of domestic investment (Figure 9). Domestic investment would rise during the next few years, prompted by the rise in public and national savings, and then decline gradually. The difference between saving and investment, that is, the current account deficit, would be close to $5 \%$ of GDP in the next 5 years and then decline to about $2 \%$ by the end of the simulation period. The larger initial current account deficit is consistent with the assumed increase in net foreign liabilities from $45 \%$ to $60 \%$ of GDP in the next 15 years.

Figure 9. Saving, Investment, and the Current Account under the Reform Scenario TFP Growth of $1.75 \%$ per Year

Public Savings Raised to $1.5 \%$ of GDP by 2013

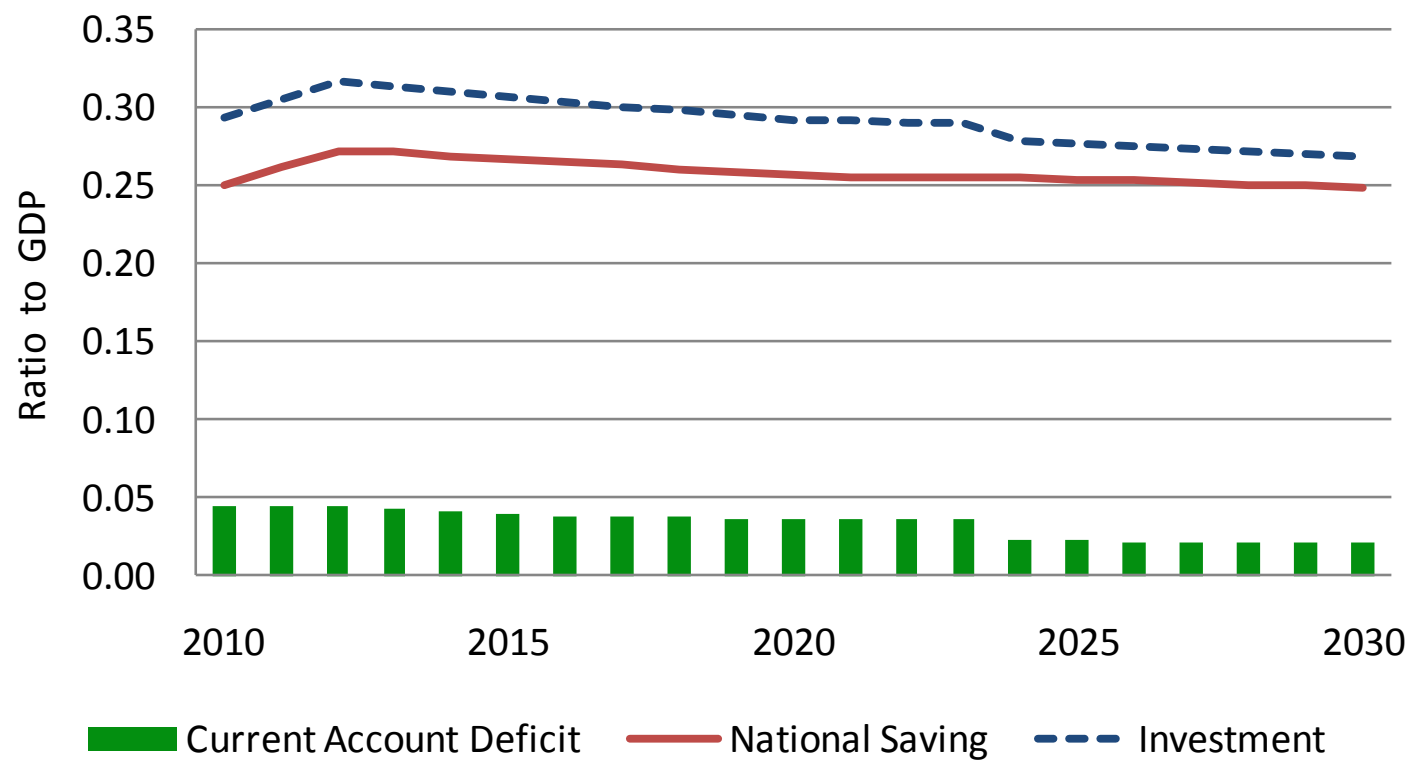

Source: Authors' calculations

The Solow decomposition presented in Figure 8 indicates that in the next five years, physical capital accumulation would account for two-thirds and TFP improvements for about $30 \%$ of GDP growth. The relative contribution of the factors of production to economic growth would not be constant over time, however. It would change over the course of the simulation period, as shown in Figure 10. As noted before, in the first years, capital accumulation would contribute by far more than any other production factor to economic growth. However, its 
relative contribution would decline as the capital stock grows and, therefore, faces diminishing returns. Over the course of the simulation period, the capital-output ratio would gradually increase from 1.3 in 2010 to 2 in 2020 and 2.25 in 2030. With an increase in this ratio, the marginal product of capital declines, and so does its contribution to GDP growth. On the other hand, the contribution of improvements in TFP would become increasingly most important, tying that of capital accumulation by 2025 and surpassing the $50 \%$ mark by 2030 . Regarding the labor input, for most of the simulation period the contribution from the labor force would be negative given that the working-age population is expected to experience a declining trend in the next two decades. The contribution of human capital would be, conversely, positive and increasing in relative terms, reaching almost $10 \%$ by 2030 . This is likely to be an underestimation of the role of human capital, however, because much of the gains in TFP could not be achieved were it not for strong human capital investment and growth.

Figure 10. Solow Growth Decomposition under the Reform Scenario Percentage Contribution of Each Factor of Production

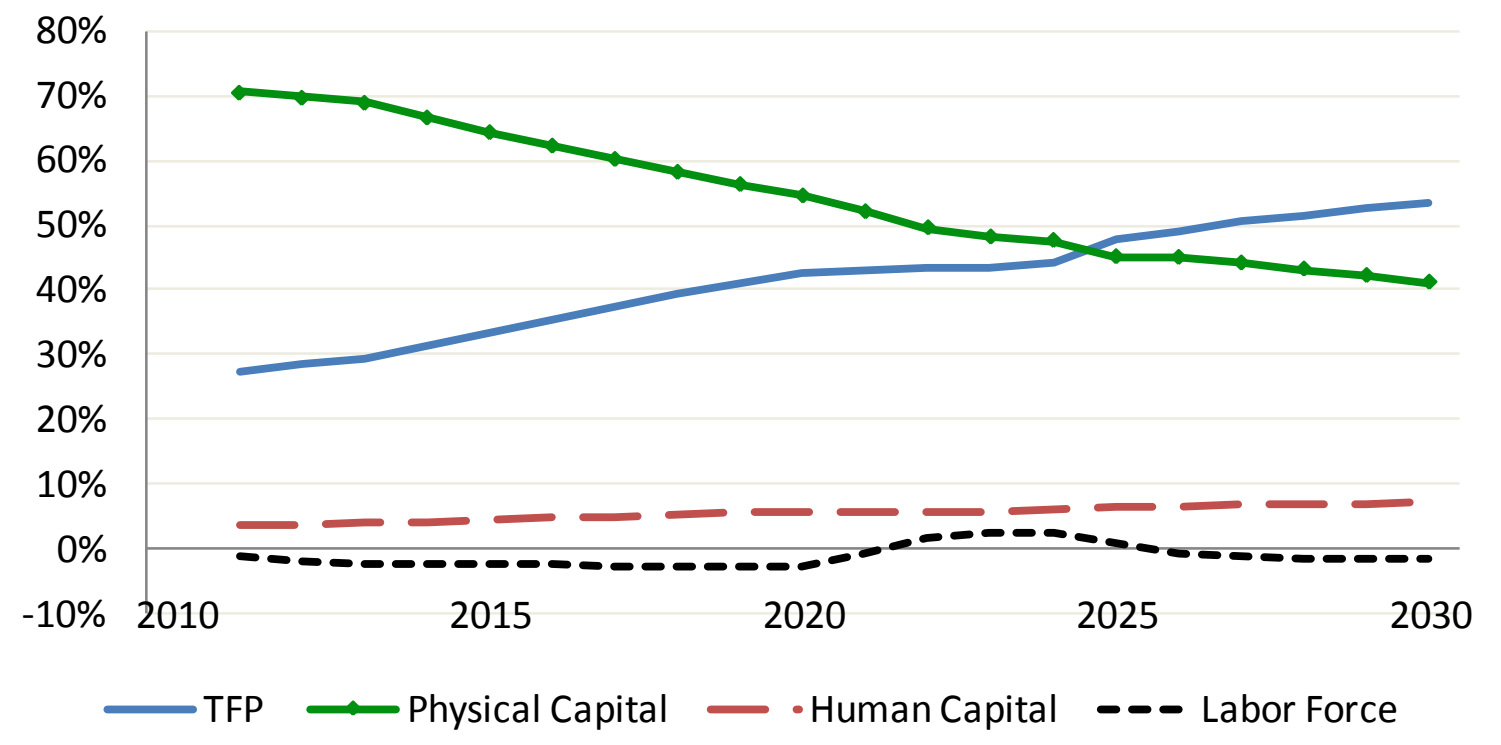

Source: Authors' calculations 


\section{Conclusions}

Even during the protracted, 25-year-long civil war, Sri Lanka's economy was able to grow at an average rate of $4.6 \%$ per year, a rate higher than three-quarters of the countries around the world. Expectations for even higher growth in the aftermath of civil conflict are, thus, understandable. This paper attempts to measure what can be projected for GDP growth in Sri Lanka in the next two decades under different scenarios for productivity improvement and public saving.

To be sure, Sri Lanka's high growth rate in the last 3 decades did not come for free. It took an increasing effort of resource mobilization in the country. In the mid 1970s, the rate of saving and investment were, respectively, $15 \%$ and $17 \%$ of GDP. By 2010 , they reached $25 \%$ and $28 \%$, respectively, an increase of at least 10 percentage points. The rise in national saving was fundamentally fueled and sustained by the private sector. Is it reasonable to expect increasing private saving rates in the future? Most likely, they will not rise much further. The demographic transition experienced in Sri Lanka indicates that in the next two decades the old dependency rate will rise considerably, producing a decline in private saving rates. This decline would be lessened if per capita income increased, as expected, but the trend would not be reversed.

Notwithstanding its high rates of capital investment in the last decades, Sri Lanka is still a country with a relatively low capital-to-output ratio and with significant infrastructure needs. The public sector, which currently features negative saving rates, has much room for reducing its deficits and increasing public investment. Similarly, external investors are likely to encounter attractive and profitable investment projects in the coming years in a reformed and peaceful environment. The government of Sri Lanka has the goals of increasing public saving to $1.5 \%$ of GDP by 2013 and allowing an increase in international investment in the country, amounting to a current account deficit of $4-5 \%$ in the coming years.

If these goals are achieved, what can be expected for GDP growth in the country? To answer this question, we have presented a neoclassical growth model with endogenous private saving, we have calibrated it to fit the Sri Lankan economy, and we have simulated the behavior 
of GDP growth rates and related variables under different scenarios. If improvements in productivity continue at the average rate experienced in the last decades (TFP growth of 1\%), GDP growth would be above $6 \%$ in the first years and then decrease gradually to about $4.5 \%$ by 2015 and a bit over $2 \%$ by 2030 . This is an adequate result but is much lower than what the Sri Lankan people and their government deem as necessary to develop. To increase growth, forceful economic and institutional reforms are needed. Under what we call the Reform Scenario, TFP growth would increase to an average rate of $1.75 \%$ per year, leading to GDP growth of about $6.5 \%$ in the next 5 years, $4.6 \%$ by 2020 , and $3.5 \%$ by 2030 , the end of the simulation period (see Table 1). This robust growth performance would be supported at the beginning mostly by capital accumulation but later on mainly by productivity improvements.

Table 1. Reform Scenario

TFP Growth of $1.75 \%$ per Year

Public Savings Raised to $1.5 \%$ of GDP by 2013

\begin{tabular}{lcccc} 
& \multicolumn{3}{c}{ Year } \\
& $\mathbf{2 0 1 2}$ & $\mathbf{2 0 1 5}$ & $\mathbf{2 0 2 0}$ & $\mathbf{2 0 3 0}$ \\
GDP per capita growth & $6.3 \%$ & $5.3 \%$ & $4.2 \%$ & $3.3 \%$ \\
GDP growth & $7.1 \%$ & $6.0 \%$ & $4.6 \%$ & $3.5 \%$ \\
Solow decomposition - Contribution (\%): & & & & \\
TFP & $28 \%$ & $33 \%$ & $42 \%$ & $53 \%$ \\
Physical Capital & $70 \%$ & $64 \%$ & $55 \%$ & $41 \%$ \\
Human Capital & $4 \%$ & $4 \%$ & $6 \%$ & $7 \%$ \\
Labor Force & $-2 \%$ & $-2 \%$ & $-3 \%$ & $-1 \%$ \\
\hline Source: Authors' & & & &
\end{tabular}

Source: Authors' calculations

The challenge, then, is how to obtain large and sustained productivity improvements, in the context of solvent fiscal accounts and international investment participation. We leave it for further work to identify the specific policy measures that can generate these essential improvements. 


\section{References}

Aizenman, Joshua, Brian Pinto and Artur Radziwill. 2007. "Sources for financing domestic capital-Is foreign saving a viable option for developing countries?" Journal of International Money and Finance. 26 (5): 682-702.

Attanasio, Orazio P., Lucio Picci and Antonello Scurco. 2000. "Saving, Growth and Investment: A Macroeconomic Analysis Using a Panel of Countries." The Review of Economics and Statistics 82 (2): 182-211.

Banerjee, Abhijit, and Esther Duflo. 2005. "Growth Theory Through the Lens of Development Economics." In Handbook of Economic Growth. Philippe Aghion and Steven N. Durlauf, eds. Vol. 1A, pp. 473-552. Amsterdam: North-Holland.

Barro, Robert, and Jong-Wha Lee. 2001. "International Data on Educational Attainment: Updates and Implications." Oxford Economic Papers 53 (3): 541-563.

Bernanke, Ben S., and Refet S. Gürkaynak. 2002. "Is Growth Exogenous? Taking Mankiw, Romer, and Weil Seriously." In NBER Macroeconomics Annual 2001, Vol. 16, ed. Ben S. Bernanke and Refet S. Gürkaynak, 11-72. Cambridge, MA: MIT Press.

Bils, Mark, and Peter J. Klenow. 2000. "Does Schooling Cause Growth?" American Economic Review 90 (5): 1160-1183.

Caselli, Francesco. 2005. "Accounting for Cross-Country Income Differences." Handbook of Economic Growth 1 (1): 679-741.

Collins, Susan M. 2007. "Economic Growth in South Asia: A Growth Accounting Perspective." In South Asia: Growth and Regional Integration, ed. Sadiq Ahmed and Ejaz Ghani, 45-60. Washington, DC: World Bank.

Duma, Nombulelo. 2007. "Sri Lanka's Sources of Growth." IMF Working Paper, WP/07/225.

Easterly, William and Ross Levine. 2001. "It's Not Factor Accumulation: Stylized Facts and Growth Models." World Bank Economic Review 15: 177-219.

Gollin, Douglas. 2002. "Getting Income Shares Right." Journal of Political Economy. Vol 110(2): 458-474.

Hall, Robert E., and Jones, Charles I. 1999. "Why Do Some Countries Produce So Much More Output Per Worker Than Others?" Quarterly Journal of Economics 114(1): 83-116.

Hevia, Constantino and Norman Loayza. 2011. "Saving and Growth in Egypt." Mimeo. World Bank, Washington, DC. 
Klenow, Peter J., and Andrés Rodríguez-Clare. 2005. "Externalities and Growth." Handbook of Economic Growth 1 (1): 817-861.

Lane, Philip R. and Gian Maria Milesi-Ferretti. 2007. "The External Wealth of Nations Mark II: Revised and Extended Estimates of Foreign Assets and Liabilities, 1970-2004", Journal of International Economics 73, November, 223-250.

Levine, Ross. 2005. "Finance and Growth: Theory and Evidence." In Handbook of Economic Growth. Philippe Aghion and Steven Durlauf, eds. The Netherlands: Elsevier Science.

Loayza, Norman, Klaus Schmidt-Hebbel and Luis Servén. 2000. "What Drives Private Savings Across the World." The Review of Economics and Statistics 82 (2): 165-181.

Mankiw, Gregory, David Romer and David Weil. 1992. "A Contribution to the Empirics of Economic Growth." The Quarterly Journal of Economics 107 (2): 407-437

Milesi-Ferretti, Gian Maria, and Assaf Razin. 1996. Current-Account Sustainability. Princeton Studies in International Economics No. 81. Princeton, NJ: International Economics Section, Princeton University.

Son, Hyun H. 2010. “Human Capital Development." Asian Development Review 27 (2): 29-56.

Schmitt-Grohé, Stephanie and Martín Uribe. 2003. "Closing Small Open Economies." Journal of International Economics 61 (1): 163-185.

Srinivasan, Thirukodikaval N. 2005. "Productivity and Economic Growth in South Asia and China." The Pakistan Development Review 44 (4): 479-503.

Young, Alwyn. 1995. "The Tyranny of Numbers: Confronting the Statistical Realities of the East Asian Growth Experience." The Quarterly Journal of Economics 110 (3): 641-680. 